\title{
OPTIMISED FERMENTED LUPIN (Lupinus angustifolius) INCLUSION IN BARRAMUNDI (Lates calcarifer) JUVENILES DIETS
}

\author{
Binh Van $\mathrm{Vo}^{1,2,{ }^{*}}$, Dien Phan Phan ${ }^{2}$, Huy Quang Nguyen ${ }^{2}$, Ravi Fotedar ${ }^{1}$ \\ (') Curtin University, Australia \\ $\left.{ }^{2}\right)$ Research Institute for Aquaculture No1, Vietnam \\ (*) Corresponding author: tel. +61420697088/+84964376315; email. binhvanvo@yahoo.com (Binh Van Vo) \\ ABSTRACT
}

The study aimed to investigate if fermentation of sweet lupin, Lupinus angustifolius, increases inclusion level of the lupin by replacing fishmeal content in the formulated diets of juvenile barramundi. Sweet lupin kernel was fermented by Lactobacilli $\left(3.10^{8} \mathrm{CFU} / \mathrm{g}\right.$ ) for 72 hours to be used to replace fishmeal at $0,30,45,60$ and $75 \%$ of inclusion levels. The results showed that the fermentation of lupin significantly reduced the amount of antinutrients and improved the amino acid profile of the lupin. The growth rates of the juvenile barramundi were not adversely affected by the different inclusion levels of fermented lupin in the diets. There was an even significant increase in the final weight and length of the barramundi fed $45 \%$ and $60 \%$ fishmeal replacement diets. The survival rates were more than $93 \%$ in all dietary treatments. Feed conversion rates (FCR) were unchanged among the diets, except significantly higher FCR shown in $75 \%$ fishmeal replacement diet. The differences of protein digestibility among diets were not significant. However, hydrolyzed fat and phosphorus in the diets significantly increased $(p<0.05)$ when the fermented lupin inclusion level rose from $30 \%$ to $75 \%$. Fish carcass protein, fat and energy contents were not significantly affected by any diet, while essential amino acid profiles revealed a little change. In conclusion, the fermentation by Lactobacilli improved the lupin's nutritional quality, allowing higher inclusion level in barramundi diets.

Keywords: Lupin, fermented, barramundi, optimum level, diets

\section{Introduction}

The dependence of fishmeal based protein source for aqua-feed has long been realized as a significant limitation for sustainable development of aquaculture (Tacon, 1997; Tacon and Metian, 2008). Therefore, alternative high protein raw materials from animal by-product or plants are currently getting attention (Wanga et al., 2006; Gatlin et al., 2007). Lupins (Lupinus spp.), have been successfully tested as potential fishmeal replacements for salmonids and several other marine species (Carter and Hauler, 2000; Glencross et al., 2004a; Glencross et al., 2004b; Glencross and Hawkins, 2004; Glencross et al., 2005; Glencross et al., 2008; Katersky and Carter, 2009) and now are used in commercial diets (Glencross and Hawkins, 2004). Lupins at $40 \%$ inclusion level also produced unchanged growth and nitrogen retention in barramundi (Lates calcarifer) (Williams, 1998).

Although lupin and other legume seeds (Phaseolus aureus, Cajanus cajan, Canavalia ensifomis) contain a high amount of protein, their uses in food and aqua-feed are still limited due to their low protein digestibility and the presence of several anti-nutritional factors (ANFs) (Mubarak, 2005). Sweet lupin (Lupinus angustifolius), contains large amounts of soluble and insoluble non-starch polysaccharides, oligosaccharides, phytates, and tannins that have anti-nutritional effects including reduced digestion and absorption of amino acids (Barneveld, 1999; Glencross et al., 2003). It has been suggested that lupins may also affect the structure of the gastrointestinal tract of salmonids (Farhangi and Carter, 2001; Refstie et al., 2005) which might potentially affect amino acid flux and subsequent protein metabolism.

To enhance bioavailability of micronutrients in plant based diets by eliminating ANFs, several methods such as thermal and mechanical processes, fermentation, soaking and germination/malting can be applied (Hotz and Gibson, 2007). For improving utilization of plant protein in aqua-feed, fermentation seems to be cost effective method due to its simplicity and requirements for low operational energy and investment (Kang et al., 2010). It is expected that lactobacilli fermentation of sweet lupin could improve its quality by reducing ANFs, improving amino acid balance and increasing digestibility thereby could increase its inclusion levels in the feed. However, pretreatment of lupin by fermentation to use as a source of protein for fish diets has never been investigated. Therefore, this study aims to evaluate the digestibility, growth performance and body composition of barramundi juveniles when fed different inclusion levels of lupin fermented by Lactobacillus sp. 


\section{Materials and methods}

\subsection{Experimental design}

Barramundi (Lates calcarifer) juveniles were obtained from Northern National Marine Broodstock Centre, Haiphong, Vietnam and shipped to National Freshwater Breeding Centre (NBC), Haiduong, Vietnam where the juveniles were raised until they were adapted to salinity of $5 \mathrm{ppm}$. The fish were then acclimated for two weeks by feeding with Uni-President, Binhduong, Vietnam feed (45\% protein, $12 \%$ fat). The juveniles were then graded, and those within the weight range of $7.0 \pm 1.6 \mathrm{~g}$ were selected and 600 fish were randomly delivered into fifteen tanks

(40fish/tank) of $3.5 \mathrm{~m}^{3}$, each attached to independent recirculating water system. The culture systems were set up out-doors in an open shed with a roof to protect from rain and direct sunlight. The natural temperature and photoperiod ranged between $28-31^{\circ} \mathrm{C}$ and 12 hours of light respectively. After acclimation the experimental fish were fed for 61 days with 5 different pre-designed diets (Table 2). Every diet was fed in triplicate and three times daily ( $8 \mathrm{am}, 12$ am and 4 pm). Feeding was modified to 90\% ASA-IM (American Soybean Association-International Marketing) satiation technique of which fish were fed to satiety for 20 minutes; the uneaten feed was collected immediately and measured in a calculation to determine amount of the feed intake; this amount was used for next 5 days and continued with another amount determined as outlined. After 61 days, the experiment was continued for another 7 days to determine digestibility by feeding with the same diets after $1 \% \mathrm{Cr}_{2} \mathrm{O}_{3}$ as an inert biomarker was added to them.

\subsection{Fermentation of lupin}

Sweet lupin, Lupinus angustifolius kernels, were provided by Co-operative Bulk Handling Grain, Perth, Western Australia. The kernels were grounded to less than $200 \mu \mathrm{m}$ before fermenting by Lactobacillus spp. Lactobacillus acidophilus, L. aporogenes and L. kefiri, were obtained from a commercial product BIOLAC, BIOPHARCO, Nhatrang, Vietnam, and then mass incubated in MRS broth medium (Merck KgaA, Darmstadt, Germany) containing polysorbate, acetate, magnesium and manganese, which are known to act as special growth factors for Lactobacillus spp. To each 1000-ml of distilled water was added $55 \mathrm{~g}$ MRS broth and 250-ml soy extract. The combination was autoclaved at $121^{\circ} \mathrm{C}$ for 15 minutes prior to the lactobacilli species being added. The incubation was carried out in a black glass jar with minimum oxygen for 24 hours at $37^{\circ} \mathrm{C}$ in a refrigerated incubator (Scientifica, VELP, Usmate, Italy). After incubation samples were collected to check if bacterial density was $>10^{8}$ CFU ml ${ }^{-1}$ (by diluted samples in $0.85 \% \mathrm{NaCl}$ water to $10^{-5}, 10^{-6}, 10^{-7}$ and cultured in MRS algae at $30^{\circ} \mathrm{C}$ for 24 hours), while the remaining part was mixed with autoclaved lupin in a plastic bag where commercial $\mathrm{N}_{2}$ gas (obtained from Hai Duong Gas Company, HCM city, Vietnam) was filled to increase anaerobic conditions. The lupin fermentation was conducted at $37^{\circ} \mathrm{C}$ for 72 hours. After fermentation, the samples of the lupin were collected to count bacterial density and nutritional profile.

\subsection{Diets preparation}

Diets were designed based on the nutritional composition of raw materials (Table 1 ) to meet $45 \%$ protein and $13 \%$ lipid levels. The five experimental diets having five inclusion levels, viz. $0 \%, 30 \%, 45 \%, 60 \%$ and $75 \%$, of fermented lupin (FL) replacing fishmeal were prepared and labelled as OFMR (control), 30FMR, 45FMR, 60FMR and 75FMR respectively (Table 2). Two sets of diets were prepared; one set was without chrome oxides (Table 2), and in the other set $1 \%$ of chrome oxide as an inert marker was added. The chrome oxide was added by replacing a part of cassava meal and wheat flour (for 75FMR) in the formulation thus protein content in diets was not affected (Table 2). The diet OFMR contained $630 \mathrm{~g} \mathrm{~kg}^{-1}$ fishmeal. Diets were processed by addition of water to about $35 \%$ mash dry weight with well mixing to form a dough. This dough was then screw pelleted by a laboratory pelletizer to $1.2-2$ $\mathrm{mm}$ pellets. These moist pellets were oven dried at $60^{\circ} \mathrm{C}$ for 12 hours followed by cooling at room temperature before storing at $-20^{\circ} \mathrm{C}$ till further use.

\subsection{Nutritional analyses}

Fermented and unfermented lupin samples were sent to LAREAL LAB in HCM city, Vietnam, for nutrients and antinutrients analyses. Nutrient parameters were analyzed in accordance with AOAC (1996). These consisted of crude protein (Kjeldalh), hydrolyzed fat (ISO 6492:1999), crude fiber (OACS Ba-6a-05), phosphorus (AOAC 965.17), and amino acid profile (HPLC), tannins (Spectrometry, Embaby, 2011) and phytic acid (Enzymatic, Haddad et al., 2007) and energy (Table 1; Table 3). 


\subsection{Fish handling and sampling}

Before the commencement of the experiments, nine (9) fish were randomly selected and pooled into 3 groups for initial carcass analyses. The body parts, without tail, fins, intestine and head were collected for body composition analyses. The body parts were dried at $105^{\circ} \mathrm{C}$ for 24 hours in a vacuum oven Shel Lab, Cornelius, USA (model 14452) at Environment and Disease Monitoring in Aquaculture, Bacninh, Vietnam, before sending to analyze crude protein and fat, energy and amino acid profile.

All fish handling activities were performed according to the Australian Code of Practice for the care of animals for science purposes, Approval No AEC_2014_14. Measurement of weight and length was carried out under an application of 2-phenoxyethanol anesthetic with a dose of $0.2 \mathrm{ml} / \mathrm{l}$ and $0.5 \mathrm{ml} / \mathrm{l}$ to humanely kill the fish for body composition analyses (Tsantilas et al., 2006). To evaluate growth, daily specific growth rate, feed conversion rates, and feed intake, all the fish at the beginning were measured for individual length and weight. At the end of experiments, 20 fish in each tank were randomly selected to measure length and weight. The digestibility analyses was performed by using fecal sedimentation method (Cho and Slinger, 1979). In every tank, a feeding tray was installed to collect all uneaten feed and if any feed escaped into the water column was siphoned immediately. After one hour of feeding, settled feces at the tank bottom were collected by siphoning, and frozen to $-20^{\circ} \mathrm{C}$ until further analyses. After 61 days of feeding test diets, one (1) fish from every tank was randomly selected to get 15 fish samples (3 samples/treatment) for final carcass analyses.

\subsection{Calculations}

Specific growth rate was calculated as: $\left.S G R=\left[\ln W_{2}-\ln W_{1}\right) /\left(t_{2}-t_{1}\right)\right]^{* 100}$; where $W_{1}$ and $W_{2}$ are body weight at start and at the end of the experiments, respectively and $t_{2}-t_{1}$ is the culture period (days). Condition index (K) was determined based on length $(\mathrm{L})$ and weight $(\mathrm{W})$ using Fulton (1904) formulas as: $\mathrm{K}=100 * \mathrm{~L} / \mathrm{W}^{3}$ while skewness value was statistically calculated as: $S=\left[1 / n \sum_{i=1}^{n}\left(x_{i}{ }^{-}\right)^{3}\right] /\left[\left[1 / n \sum_{i=1}^{n}\left(x_{i}-\bar{x}\right)^{2}\right]^{3 / 2} ;\right.$ where $x_{i}$ and $n$ denote for the individual and observation, $\bar{x}$ was the sample mean. Apparent digestibility coefficients (ADC) of each nutritional component of the diets was calculated as: $A D C=100-100 *[$ Marker in feces(\%)/Marker is diets (\%)]*[Nutrient (i) in feces (\%)/Nutrient (i) in diet (\%)]; where (i) is a single nutrient like crude protein or hydrolyzed fat. Ingredient ADC was calculated as described by Forster (1999) and Glencross et al. (2007) as: $A D C_{\text {ing }}=[100-$ $\mathrm{j}) *\left(\right.$ Nutr $_{\text {re }}+$ Nutr $\left._{\text {ing }} * \mathrm{j}\right) *\left(A D C_{\text {test }}-\left((100-\mathrm{j}) *\right.\right.$ Nutr $\left.\left._{\text {re }} * A D C_{\text {re }}\right)\right] /\left[\right.$ Nutr $\left._{\text {ing }} * j\right]$; where $\mathrm{j}$ is percentages of FL replaced fishmeal proportion, Nutr re $_{\text {and Nutr }}$ ing are given nutrients in reference diet and $F L$, respectively and $A D C_{\text {ing, }} A D C_{r e}$ and $A D C_{\text {test }}$ are digestibility coefficients of $\mathrm{FL}$, reference diet and test diet respectively. Nutrient retention was calculated as \% of nutrient intake.

\subsection{Statistical analysis}

The data were analyzed using SPSS for Windows version 18, IBM, Curtin University, Australia and Stata SE 12, Lakeway Drive, Texas, USA with the results expressed as the means and pooled standard errors of the mean (S.E.M). Paired-sample T Test was used to compare means of single nutritional parameter of the lupin before and after fermentation. One-way analysis variance (ANOVA) was used to compare effects of diets without and with different fermented lupin inclusions into the diets. Size distribution presented in the skewness values was performed together with normal distribution test. Levels of significance were determined for length and weight (Bonferroni), condition index, body composition (Tukey's HSD), digestibility, and growth performance (Least Significance Difference planned comparisons), with significant limits being set at $p<0.05$.

\section{Results}

\subsection{Fermentation of lupin}

Bacterial density found in fermented product was $3.10^{8} \mathrm{CFU} / \mathrm{g}$. There were differences in anti-nutrients and amino acid profile before and after the lupin was fermented. While two anti-nutrients, tannins and phytic acid were significantly reduced by $87.04 \%$ and $17.64 \%$ respectively, the amino acids, lysine, methionine, as well as phosphorus availability were increased (Table 1, Table 3).

\subsection{Growth performance}

There were some significant differences in final weight and length among fish fed the different diets (Table 4). Fish grew to a higher weight $(p<0.05)$ when fed diets 45FMR and 60FMR than the control diet $(0 F M R)$, while those fed 
30FMR and 75FMR did not show any growth increases. The juvenile barramundi length increased significantly when they were fed 60FMR and decreased when fish fed 75FMR than OFMR, whereas 30FMR and 45FMR resulted in unchanged growth of the fish. There was no difference in specific growth rate (SGR) between control and test diets.

The survival of the fish of all diets was more than 93\% (Table 4). Among them, diet 30FMR yielded the highest survival (98\%) and was significantly higher than the control and other test diets. In contrast, feed conversion rates (FCR) were not significantly different among any diets except the 75FMR which produced the higher FCR $(p<0.05)$.

The length and weight distribution (Figure 1, Figure 2) and skewness (Table 4) showed the various patterns in sizes of fish within each group fed different diets. The variations in length and weight were similar to the control and test diets, despite the fact that the shorter and lighter fish were found in 75FMR diet. In contrast, the $\mathrm{K}$ indices, indicating a fatness of the fish, were significantly different among fish fed various diets. The fatness calculated from condition indices of fish fed FL diets was not significantly different with the control diet. However, in general, fish were significantly less fat when fed diets 30FMR, 45FMR and 60FMR than fed 75FMR.

\subsection{Digestibility}

Apparent digestibility coefficient (ADC) of protein was not significantly different among diets. Whereas, there were significant differences in ADC of hydrolyzed fat, energy, fiber and phosphorus levels between control and test diets (Table 5). While, 30FMR diet resulted in significantly lower ADC of hydrolyzed fat and energy than control, 45FMR, 60FMR and 75FMR diets produced higher ADC of hydrolyzed fat and energy. When the FL inclusion levels increased in diets, the ADC of phosphorus correspondingly increased.

The ADC of ingredient-FL showed no significant differences of ADC of protein and phosphorus (Table 5). However, ADC of hydrolyzed fat and energy of ingredient-FL was higher in 60FMR and 75FMR diets than of 30FMR and 45 FMR diets. Meanwhile, ADC of fiber of ingredient-FL was significantly different between 75FMR and the lowered inclusion level diets.

\subsection{Body composition}

Proximate protein content (\%) in initial fish and fish fed control diet were higher $(p<0.05)$ than fish fed FL diets (Table 6). All FL diets resulted in the similar carcass proximate protein levels while the fish fed the control diet did not change in carcass protein compared to the fish before the experiment commenced. The carcass fat and energy levels of the initial fish were significantly higher than those of the fish fed any test diets. No significant difference in carcass fat and energy levels were found in any fish fed test diets. The percentages of essential amino acids (EAA) such as histidine (His) and tryptophan (Try) of carcass of initial fish and fish fed test diets were similar, whereas remaining EAA were significantly different. Met of fish fed OFMR was higher than the initial fish and fish fed FL inclusion diets (Table 6).

There was significant differences in protein retention between fish fed control (OFMR) diet and FL inclusion diets (Table 7). However, when FL inclusion level increased, protein retention was unchanged. Neither fish fed fishmeal nor different inclusions of FL in diets significantly resulted in the change of fat and energy retentions.

\subsection{Interactions}

There was no significant interaction between inclusion levels of FL and blood meal; tannins and phytates; and FL and cassava. A closed significant ( $p=0.07$ ) interaction was observed between $\mathrm{FL}$ and inclusion levels of wheat flour. The variations in FCR and $A D C$ of phosphorus were significantly related to $\mathrm{FL}$ inclusion levels and concentration of ANFs (Table 8, Figure 3).

\section{Discussion}

A number of ANFs are present in protein-rich plants (Francis et al., 2001) including lupins (Dupont et al., 1994). Sweet Australia lupin is low in alkaloids (Dupont et al., 1994) however phytates and tannins are major factors influencing the digestibility and thus reduces growth performance in aquatic species. Tannins contents are 1.17 and $2.64 \mu \mathrm{g} \mathrm{g}^{-1}$ in sweet and bitter lupins respectively (Dupont et al., 1994) that influence the protein utilization and digestion (Francis et al., 2001). These ANFs are rather stable under heat treatment (Boland et al., 1975) but can be efficiently removed by fermentation (Nnam and Obiakor, 2003). Lactic acid fermentation has been shown to give a significant reduction in phytic acid in cereals and sesame seed (Marklinder et al., 1996; Mukhopadhyay 
and Ray, 1999; Skrede et al., 2002). Bartkiene et al. (2013) indicated that Lacto-fermentation of sweet lupin (L. angustifolius) could reduce acrylamide in enriched bread with high quality protein. Phytic acid and tannins in fermented lupin were reduced by $27.3 \%$ and $10.7 \%$, respectively after 9 hours of fermentation by traditional method (Dhankher and Chauhan, 1987). Fermentation is the most effective way in decreasing the 56-96\% of phytic acid than soaking and germination of brown rice (Liang et al., 2008).

In this study, the fermentation by Lactobacillus sp. significantly decreased the levels of phytic acid and tannins by $87.04 \%$ and $17.64 \%$ respectively. These reductions are crucial to increase the inclusion levels of FL diets as high concentration of these ANFs can be detrimental to growth, for instance $0.5 \%$ purified phytic acid supplemented in feed can reduce $10 \%$ growth rate in rainbow trout (Spinelli et al., 1983). Although other ANFs such as saponins, oxalate and cyanogenic glycosides, were not evaluated in the present study, they are also reduced when raw materials are fermented (Ketiku et al., 1978; Eka, 1980; Fenwick and Oakenfull, 1983).

Sweet lupin had a little effect on the palatability of fish. The mixture of lupin kernel and lupin concentrate in barramundi juvenile diets did not influence to palatability (Katersky and Carter, 2009). Similarly, Glencross et al. (2011) demonstrated that a threshold where diets' palatability was maintained at $150 \mathrm{~g} \mathrm{~kg}^{-1}$ fishmeal with lupin, contributed $425 \mathrm{~g} \mathrm{~kg}^{-1}$ diet. In the present study feed intake was not reduced in any fish, with the highest inclusion level of FL was at $400 \mathrm{~g} \mathrm{~kg}^{-1}$ (60FMR) diet. This could be due to low alkaloids presence in the lupin, as the alkaloids result in a bitter taste and fermentation of lupin can improve aroma for the diets (Schindler et al., 2011b).

After 61 days of culture, the barramundi juveniles fed all diets gained greater than $30 \mathrm{~g}$ from an initial average of 7g. Unfermented lupin as a fishmeal replacing single ingredient has been evaluated in other marine species. In rainbow trout 50\% inclusion of lupin (L. angustifolius) in the diet resulted in significant reduction in the growth (Farhangi and Carter, 2001). In Atlantic salmon, the same replacement at a inclusion levels of 25 - 33\%, resulted in lower utilization (Carter and Hauler, 2000). In this study, up to $60 \%$ of fishmeal was replaced by FL which resulted in higher growth than the control diet where only fishmeal was a main source of protein.

Dependence on only fishmeal source presents considerable risks associated with supply, price and quality fluctuations (Glencross et al., 2007). Therefore, proportion of fishmeal should be reduced in a diet while maintaining a balanced nutritional formulation and thereby producing an acceptable good growth and low FCR. When fishmeal is replaced by a lower protein sources such as lupin, the blood meal has been used in accordance with the levels of FL included into diets. Concomitantly, the wheat flour and cassava meal were also used to balance the nutrients in the diets. Blood meal can be well utilized by barramundi and its added levels in these test diets were in the range that did not negatively influence to growth and FCR (Williams et al., 2003). In contrast, the carbohydrate derived from wheat flour and cassava meal could influence the growth performance as carbohydrate was used limitedly by only marine fish (McMeniman, 2003). In the present study, interaction among ingredient inclusion levels was not observed, proved in better growth rate and high digestibility of test and control diets. Additionally, after fermentation, the lupin's EAA profile was modified which formed the diets more close to EAA profile found in barramundi (Glencross, 2006). This suggests that all formulated diets in the current study were nutritionally balanced.

Length-weight composition and $\mathrm{K}$ indices are important to determine the fitness and health of the fish population (Fulton, 1904), which is also referred as a return rate of operation cost in fish culture (Engle et al., 2011). Size composition reflected by the fitted or skewed frequencies of the size (Ohlberger et al., 2013) are strongly influenced by food quantity and quality (Fuiman, 2002), and feeding regime (Wang et al., 1998). The fish in this study were more uniform when fed all FL inclusion diets than the control diet which is desirable from marketing viewpoint. The more uniform size could be explained by the feed intake, since fish eat more feed of 30FMR, 45FMR and 60FMR diets than that of control and 75FMR diets. As high inclusion level of FL in the diet formulation can reduce the feed production cost, a minimum size variation in the harvested fish size is critical for feed producers to reduce the feed costs.

Very few studies have attempted to evaluate the nutrient digestibility of FL. However, the bio-processed pretreatment for plant ingredients have proven to increase digestibility. Lactic acid (Lactobacillus sp) fermentation of oil-extracted soybean meal partly eliminates and inactivate ANFs restricting the absorption of lipids by Atlantic salmon which then leads to a higher digestibility of total dietary energy, and subsequently improved feed efficiency (Refstie et al., 2005). The addition of lupin protein concentrate and wheat gluten, exposed to certain extent of bio-processing, increases protein digestibility in diets for Atlantic salmon (Storebakken et al., 2000; Refstie et al., 2006). The digestibility in this study was higher than the study of Carter and Hauler (2000) partly due to the fecal collection method by sedimentation which can overestimate the digestibility of the nutrients 
(Glencross et al., 2007), however the main reason for the increase could be attributed to the fermentation process that reduced tannins and phytates, and others ANF's (Refstie et al., 2005), improved amino acid profile (Yabaya et al., 2009) and aroma (Schindler et al., 2011a).

The results in this study were in agreement with Carter and Hauler (2000) where inclusion of sweet lupin resulted in a significant increase in digestibility of crude protein but no changes in energy levels. An combination of different plant ingredients also increased digestibility in juvenile barramundi (Glencross et al., 2011). Apparent digestibility of phosphorus was affected by the inclusion levels of $F L$ in diets with a strong regression $\left(R^{2}=0.97\right)$. This was explained by the content of digestible phosphorus which was high in lupin ingredient and the fermentation process leads to increase in digestibility of phosphorus as shown in pigs (Almeida and Stein, 2012).

There was no change in proximate compositions among fish fed test diets. The results in this study were similar to the finding on cuneate drum (Nibea miichthioides) fed soybean substituting fishmeal (Wang et al., 2006) where carcass protein also remained unchanged. The higher level of protein, fat and energy contents in initial carcass in the present study could be explained by the age and the diets. Initial fish were smaller and were fed on both trash fish and commercial feed before they were stocked to the test facility. The EAA in barramundi carcass in this study was similar as reported by Glencross (2006). In general, there was little relationship between EAA in FL which reflected in test diets and the EAA in carcass. Some EAA, Iso, Leu, Lys, Phe and Val were higher in FL than fishmeal, but these were not differences in carcass between fish fed OFMR and FL inclusion diets. Met in FL was higher than fishmeal, however Met in carcass of OFMR was higher with FL inclusion, suggesting that the Met was not well utilized by the fish.

Fermentation of sweet lupin, L. angustifolius by Lactobacillus sp, resulted in the elimination and/or inactivation of ANFs that restrict the absorption of nutrients by barramundi juvenile. This led to higher digestibility of crude protein, hydrolyzed fat and phosphorus which in turn resulted in an improved feed efficiency. The fermentation also improved lupin quality, reflecting in the acceptance of the fish with high inclusion level of the FL in test diets. Even though the protein retention in control diet was higher than in test diets, increased levels of FL inclusion did not change the retentions of protein, fat and energy. In addition, the body composition was the same among any fish fed any test diet, suggesting that high inclusion of $\mathrm{FL}$, up to $60 \%$ could result in higher growth in barramundi juveniles.

\section{Acknowledgment}

The authors would like to acknowledgment Research Institute for Aquaculture No1 where experiments were carried out, the LAREAL LAB Vietnam for technical assistance in the laboratory work. Special thanks also to David Fienberg and Chris Saunders from CBH Grain, Western Australia, who kindly gave the lupin for this study. The authors also acknowledge Associate Professor Nguyen Duc Quang from Corvinus University of Budapest, Hungary and Mr. Nguyen Hai Son from Mekong River Commission for editorial contributions of the manuscript. The research was financially supported by PhD program of Curtin International Postgraduate Research Scholarships (CIPRS) in conjunction with Ministry of Education and Training Vietnam (MoET) Award.

\section{Reference}

Almeida, F.N., Stein, H.H., 2012. Effects of graded levels of microbial phytase on the standardized total tract digestibility of phosphorus in corn and corn coproducts fed to pigs. J. Anim. Sci 90, 1262-1269.

Barneveld, R.J.v., 1999. Understanding the nutritional chemistry of lupin (Lupinus spp.) seed to improve livestock production efficiency. Nutr. Res. Rev 12, 203-230.

Bartkiene, E., Jakobsone, I., Juodeikiene, G., Vidmantiene, D., Pugajeva, I., Bartkevics, V., 2013. Effect of lactic acid fermentation of lupine wholemeal on acrylamide content and quality characteristics of wheatlupine bread. Intl. J. Food Sci. Nutr 64, 890-896.

Boland, A.R.D., Garner, G.B., O'Dell, B.L., 1975. Identification and properties of phytate in cereal grains and oilseed products. Journal of Agricultural and Food Chemistry 23, 1186-1189.

Carter, C.G., Hauler, R.C., 2000. Fish meal replacement by plant meals in extruded feeds for Atlantic salmon,Salmo salar L. Aquaculture 185, 299-311. 
Cho, C.Y., Slinger, S.J., 1979. Apparent digestibility measurement in feedstuff for rainbow trout. In: Finfish Nutrition and Fishfood Technology. (Halver, J.E. \& Tiews, K. eds). Heenemann GmbH, Berlin 2, 239-247.

Dhankher, N., Chauhan, B.M., 1987. Effect of temperature and fermentation time on phytic acid and polyphenol content of rabadi-a fermented pearl millet food. Journal of Food Science 52, 828-829.

Dupont, M.S., Muzquiz, M., Estrella, I., Fenwick, G.R., Price, K.R., 1994. Relationship between the sensory properties of lupin seed with alkaloid and tannin content. J. Sci. Food Agri 65, 95-100.

Eka, O.U., 1980. Effect of fermentation on the nutrient status of locust beans. Food Chemistry 5, 303308.

Embaby, H.E.-S., 2011. Effect of Heat Treatments on Certain Antinutrients and in vitro Protein Digestibility of Peanut and Sesame Seeds. Food Science and Technology Research 17, 31-38.

Engle, C.R., Southworth, B., Sudhakaran, P.O., Nanninga, A., 2011. Production and economic effects of in-pond grading of channel catfish. Aquacultural Engineering 45, 1-8.

Farhangi, M., Carter, C.G., 2001. Growth, physiological and immunological responses of rainbow trout (Oncorynchus mykiss) to different dietary inclision levels of dehulled lupin (Lupinus angustifolius). Aquaculture Research 32, 329-340.

Fenwick, D.E., Oakenfull, D., 1983. Saponin content of food plants and some prepared foods. Journal of the Science of Food and Agriculture 34, 186-191.

Forster, I., 1999. A note on the method of calculating digestibility coefficients of nutrients provided by single ingredients to feeds of aquatic animals. Aquaculture Nutrition 5, 143.

Francis, G., Harinder, P.S., Makkar, Becker, K., 2001. Antinutritional factors present in plant-derived alternate fish feed ingredients and their effects in fish. Aquaculture (199).

Fuiman, L.A., 2002. Special considerations of fish eggs and larvae. Fishery science: the unique contributions of early life stages, 1-32.

Fulton, T.W., 1904. The rate of growth of fishes. . Twenty-second Annual Report, Part III. Fisheries Board of Scotland, Edinburgh, 141-241.

Gatlin, D.M., Barrows, F.T., Brown, P., Dabrowski, K., Gaylord, T.G., Hardy, R.W., Herman, E., Hu, G., Krogdahl, A., Nelson, R., Overturf, K., Rust, M., Sealey, W., Skonberg, D., Souza, E.J., Stone, D., RichWilson, EveWurtele, 2007. Expanding the utilization of sustainable plant products in aquafeeds: a review. Aquaculture Research 38, 551-579.

Glencross, B., Boujard, T., Kaushik, S.J., 2003. Influence of oligosaccharides on the digestibility of lupin meals when fed to rainbow trout,Oncorhynchus mykiss. Aquaculture 219, 703-713.

Glencross, B., Carter, C.G., Duijster, N., Evans, D.R., Dods, K., McCafferty, P., Hawkins, W.E., Maas, R., Sipsas, S., 2004a. A comparison of the digetibility of a range of lupin and soybean protein products when fed to either Atlantic salmon (Salmo salar) or rainbow trout (Oncorhynchus mykiss). Aquaculture 237, 333-346.

Glencross, B., Evans, D., Dods, K., McCafferty, P., Hawkins, W., Maas, R., Sipsas, S., 2005. Evaluation of the digestible value of lupin and soybean protein concentrates and isolates when fed to rainbow trout, Oncorhynchus mykiss, using either stripping or settlement faecal collection methods. Aquaculture 245, 211-220.

Glencross, B., Evens, D., Hawkins, W., Jones, B., 2004b. Evaluation of dietary inclusion of yellow lupin (Lupin luteus) kernel meal on the growth, feed utilisation and tissue histology of rainbow trout (Oncorhynchus mykiss). Aquaculture 235, 411-422. 
Glencross, B., 2006. The nutritional management of barramundi, Lates calcarifer - a review. Aquaculture Nutrition 12, 291-309.

Glencross, B., Hawkins, W., Evans, D., Rutherford, N., Dods, K., P.Mccafferty, Sipsass, S., 2008. Evaluation of the influence of Lupinus angustiforlius kernel meal on dietary nutrient and energy utilization of efficiency by rainbow trout (Oncorhynchus mykiss). Aquaculture Nutrition 14, 129-138.

Glencross, B., Rutherford, N., Jones, B., 2011. Evaluating options for fishmeal replacement in diets for juveniles barramundi (Lates culcarifer). Aquaculture Nutrition 17, 722-732.

Glencross, B.D., Booth, M., Allan, G.L., 2007. A feed is only as good as its ingredients-a review of ingredient evaluation strategies for aquaculture feeds. Aquaculture nutrition 13, 17-34.

Glencross, B.D., Hawkins, W.E., 2004. A comparison of the digestibility of several lupin (Lupinus sp.) kernel meal varieties when fed to either rainbow trout (Oncorhynchus mykiss) or red seabream (Pagrus auratus). Aquaculture Nutrition 10, 65-73.

Haddad, J., Greiner, R., Allaf, K., 2007. Effect of instantaneous controlled pressure drop on the phytate content of lupin. LWT-Food Science and Technology 40, 448-453.

Hotz, C., Gibson, R.S., 2007. Traditional Food processing and preparation practices to enhance the bioavailability of micronutrients in plant based diets. Journal of Nutrition 173, 1097-1100.

Kang, H.Y., Yang, P.Y., Dominy, W.G., Lee, C.S., 2010. Bioprocessing papaya processing waste for potential aquaculture feed supplement - Economic and nutrient analysis with shrimp feeding trial. Bioresource Technology 101, 7973-7976.

Katersky, R.S., Carter, C.G., 2009. Growth and protein synthesis of barramundi, Lates calcarifer, fed lupin as a partial protein replacement. Comparative Biochemistry and Physiology Part A: Molecular \& Integrative Physiology 152, 513-517.

Ketiku, A.O., Akinyele, I.O., Keshinro, O.O., Akinnawo, O.O., 1978. Changes in the hydrocyanic acid concentration during traditional processing of cassava into 'gari' and 'lafun'. Food Chemistry 3, 221-228.

Liang, J., Han, B.-Z., Nout, M.J., Hamer, R.J., 2008. Effects of soaking, germination and fermentation on phytic acid, total and in vitro soluble zinc in brown rice. Food chemistry 110, 821-828.

Marklinder, I.M., Haglund, Johansson, L., 1996. Influences of lactic acid bacteria on technological, nutritional and sensory properties of barley sour dough bred. Food Quality Preference 7, 285-292.

McMeniman, N., 2003. Digestibility and Utilization of starch by barramundi In Aquaculture Diet Development Subprogram: Ingredient Evaluation. Final report to the Fisheries R\&D Coporation, Canberra, Australia.

Mubarak, A.E., 2005. Nutritional composition and antinutritional factors of mung bean seeds (Phaseolus aureus) as affected by some home traditional processes. Food Chemistry 89, 489-495.

Mukhopadhyay, N., Ray, A.K., 1999. Effect of fermentation on the nutritive value of sesame seed meal in the diets for Rohu, Labeo rohita (Hamilton) fingerlings. Aquaculture Nutrition 5, 229-236.

Nnam, N.M., Obiakor, P.N., 2003. Effect of fermentation on the nutrient and antinutrient composition of baobab (adansonia digitata) seeds and rice (oryza sativa) grains. Ecology of Food and Nutrition 42, 265277.

Ohlberger, J., Otero, J., Edeline, E., Winfield, I.J., Stenseth, N.C., Vøllestad, L.A., 2013. Biotic and abiotic effects on cohort size distributions in fish. Oikos 122, 835-844.

Refstie, S., Glencross, B., Landsverk, T., Sørensen, M., Lilleeng, E., Hawkins, W., Krogdahl, A., 2006. Digestive function and intestinal integrity in Atlantic salmon (Salmo salar) fed kernel meals and protein concentrates made from yellow or narrow-leafed lupins. Aquaculture 261, 1382-1395. 
Refstie, S., Sahlstrom, S., Brathen, E., Baeverfjord, G., Krogedal, P., 2005. Lactic acid fermentation eliminates indigestible carbohydrates and antinutritional factors in soybean meal for Atlantic salmon (Salmo salar). Aquaculture 246 331-345.

Schindler, S., Wittig, M., Zelena, K., Krings, U., Bez, J., Eisner, P., Berger, R.G., 2011a. Lactic fermentation to improve the aroma of protein extracts of sweet lupin (Lupinus angustifolius). Food chemistry 128, 330-337.

Schindler, S., Wittig, M., Zelena, K., Krings, U., Bez, J., Eisner, P., Berger, R.G., Adeparusi, E.O., 2011 b. Lactic fermentation to improve the aroma of protein extracts of sweet lupin (Lupinus angustifolius). Food Chemistry 128, 330-337.

Skrede, G., Storebakken, T., Skrede, A., Sahlstrbm, S., Sbrensen, M., Shearer, K.D., Slinde, E., 2002. Lactic acid fermentation of wheat and barley whole meal flours improves digestibility of nutrients and energy in Atlantic salmon (Salmo salar L.) diets. . Aquaculture 210, 305-321.

Spinelli, J., Houle, C.R., Wekell, J.C., 1983. The effect of phytates on the growth of rainbow trout (Salmo gairdneri) fed purified diets containing varying quantities of calcium and magnesium. Aquaculture 30 , 71-83.

Storebakken, T., Shearer, K.D., Baeverfjord, G., Nielsen, B.G., Åsgård, T., Scott, T., Laporte, A.D., 2000. Digestibility of macronutrients, energy and amino acids, absorption of elements and absence of intestinal enteritis in Atlantic salmon, Salmo salar, fed diets with wheat gluten. Aquaculture 184, 115132.

Tacon, A.G.J., 1997. Feeding tomorrow's fish: Keys for sustainability. In: Tacon A.G.J. (ed.), Basurco B. (ed.). Feeding tomorrow's fish. Zaragoza : CIHEAM: 11-33 (Cahiers Options Méditerranéennes; n. 22).

Tacon, A.G.J., Metian, M., 2008. Global overview on the use of fishmeal and fishoil in industrially compounded aquafeeds: trends and future prospects. Aquaculture 285, 146-158.

Tsantilas, H., Galatos, A.D., Athanassopoulou, F., Prassinos, N.N., Kousoulaki, K., Carter, C.G., 2006. Efficacy of 2-phenoxyethanol as an anaesthetic for two size classes of white sea bream, Diplodus sargus L., and sharp snout sea bream, Diplodus puntazzo C. Aquaculture 253, 64-70.

Wang, N., Hayward, R.S., Noltie, D.B., 1998. Effect of feeding frequency on food consumption, growth, size variation, and feeding pattern of age-0 hybrid sunfish. Aquaculture 165, 261-267.

Wang, Y., Kong, L.J., Li, C., Bureau, D.P., 2006. Effect of replacing fish meal with soybean meal on growth, feed utilization and carcass composition of cuneate drum (Nibea miichthioides). Aquaculture 261, 13071313.

Wanga, Y., Jin-lu Guoa, Bureaub, D.P., Cuia, Z.-h., 2006. Replacement of fish meal by rendered animal protein ingredients in feeds for cuneate drum (Nibea miichthioides). Aquaculture 252, 476-483.

Williams, K.C., 1998. Efficacy of utilisation of different feed sources as measured by summit dilution. Fishmeal replacement in aquaculture feeds for barramundi. Final Report of Project 93/120-03 to the Fisheries Research and Development Corporation. Canberra, Australia.

Williams, K.C., Paterson, B.D., Barlow, C.G., Ford, A., Roberts, R., 2003. Potential of meat meal to replace fish meal in extruded dry diets for barramundi, Lates calcarifer (Bloch). II. Organoleptic characteristics and fatty acid composition. Aquaculture Research 34, 33-42.

Yabaya, A., Akinyanju, J.A., Jatau, E.D., 2009. Yeast enrichment of soybean cake. World Journal Dairy \& Food Sciences 4, 141-144. 
Table 1. Ingredients and diets' chemical analyzed. DM, GE, DE, CP, LOA, LNA, ARA, EPA, and DHA denote for dry matter, gross energy, digestible energy, crude protein, inolenic acid, linoleic acid, arachidonic acid, essential fatty acid, and docosahexaenoic acid.

\begin{tabular}{|c|c|c|c|c|c|c|c|}
\hline Parameters & Fermented lupin & Lupin & OFMR & 30FMR & 45FMR & $60 F M R$ & $75 \mathrm{FMR}$ \\
\hline $\mathrm{DM}(\mathrm{g} / 100 \mathrm{~g})$ & 83.00 & 89.50 & & & & & \\
\hline $\operatorname{Ash}(g / 100 \mathrm{~g})$ & 2.58 & 2.60 & & & & & \\
\hline GE MJ/kg & 20.45 & 17.10 & & & & & \\
\hline $\mathrm{DE} \mathrm{MJ} / \mathrm{kg}$ & 13.70 & 12.00 & & & & & \\
\hline $\mathrm{CP}(\mathrm{g} / 100 \mathrm{~g})$ & 40.00 & 38.55 & & & & & \\
\hline $\operatorname{Dig} C P(g / 100 g)$ & 38.20 & 35.70 & & & & & \\
\hline Lipid (g/100 g) & 5.87 & 7.80 & & & & & \\
\hline Fibre (g/100 g) & 2.58 & 4.20 & & & & & \\
\hline Arginine $(\mathrm{g} / 100 \mathrm{~g})$ & 3.90 & 4.14 & 2.56 & 2.83 & 2.96 & 2.98 & 3.09 \\
\hline Histidine (g/100 g) & 1.33 & 0.78 & 1.20 & 1.32 & 1.41 & 1.56 & 1.65 \\
\hline Isoleucine (g/100 g) & 1.84 & 1.42 & 2.00 & 1.92 & 1.84 & 1.63 & 1.56 \\
\hline Leucine $(\mathrm{g} / 100 \mathrm{~g})$ & 2.93 & 2.55 & 3.57 & 3.61 & 3.65 & 3.77 & 3.82 \\
\hline Lysine (g/100 g) & 2.23 & 1.73 & 3.39 & 3.25 & 3.15 & 3.08 & 3.02 \\
\hline Methionine $(\mathrm{g} / 100 \mathrm{~g})$ & 0.32 & 0.25 & 1.26 & 1.05 & 0.92 & 0.74 & 0.63 \\
\hline$M+C(g / 100 \mathrm{~g})$ & 0.90 & 1.00 & 1.69 & 1.52 & 1.41 & 1.25 & 1.15 \\
\hline Phenylalanine (g/100 g) & 1.70 & 1.40 & 1.99 & 2.03 & 2.07 & 2.15 & 2.18 \\
\hline$P+T(g / 100 g)$ & 3.40 & 3.20 & 3.47 & 3.57 & 3.62 & 3.67 & 3.72 \\
\hline Threonine (g/100 g) & 1.63 & 1.34 & 1.91 & 1.90 & 1.88 & 1.87 & 1.86 \\
\hline Tryptophan (g/100 g) & 0.33 & 0.33 & 0.52 & 0.50 & 0.48 & 0.47 & 0.46 \\
\hline Valine $(\mathrm{g} / 100 \mathrm{~g})$ & 1.90 & 1.40 & 2.47 & 2.47 & 2.47 & 2.54 & 2.56 \\
\hline Available P (g/100 g) & 0.23 & 0.09 & 2.96 & 2.28 & 1.84 & 1.25 & 0.87 \\
\hline
\end{tabular}


Table 2. Ingredients composition of diets' formulation for growth, FCR and feed intake determination.

\begin{tabular}{|c|c|c|c|c|c|}
\hline \multirow[b]{2}{*}{ Ingredient } & \multicolumn{5}{|c|}{ Formula \% } \\
\hline & OFMR & 30FMR & 45FMR & 60FMR & 75FMR \\
\hline Fish meal & 63.00 & 48.00 & 38.00 & 25.00 & 16.50 \\
\hline Lupin & 0.00 & 20.00 & 31.00 & 40.00 & 49.50 \\
\hline Fish oil, Salmon & 8.20 & 8.80 & 9.20 & 9.90 & 10.20 \\
\hline Wheat flour & 12.00 & 10.00 & 10.00 & 6.50 & 5.00 \\
\hline Blood meal & 4.50 & 6.50 & 8.60 & 14.00 & 16.00 \\
\hline Cassava meal & 10.44 & 4.84 & 1.34 & 2.74 & 0.94 \\
\hline Soy lecithin & 1.00 & 1.00 & 1.00 & 1.00 & 1.00 \\
\hline Vitamin PMX-F2 & 0.50 & 0.50 & 0.50 & 0.50 & 0.50 \\
\hline Mineral PMX-F1 & 0.25 & 0.25 & 0.25 & 0.25 & 0.25 \\
\hline Mold Inhibitor & 0.05 & 0.05 & 0.05 & 0.05 & 0.05 \\
\hline Stay C - 35\% & 0.03 & 0.03 & 0.03 & 0.03 & 0.03 \\
\hline Antioxidant & 0.02 & 0.02 & 0.02 & 0.02 & 0.02 \\
\hline \multicolumn{6}{|l|}{ Diets analyses } \\
\hline $\mathrm{DM}(\mathrm{g} / 100 \mathrm{~g})$ & 88.76 & 87.46 & 87.70 & 86.51 & 98.84 \\
\hline Ash (g/100 g) & 20.69 & 17.37 & 14.82 & 13.71 & 12.74 \\
\hline GE MJ/kg & 21.26 & 21.65 & 21.85 & 22.17 & 22.37 \\
\hline DE MJ/kg & 17.80 & 17.63 & 17.47 & 17.12 & 16.96 \\
\hline $\mathrm{CP}(\mathrm{g} / 100 \mathrm{~g})$ & 44.77 & 44.55 & 43.97 & 44.21 & 44.01 \\
\hline Dig CP (g/100 g) & 38.98 & 39.20 & 39.02 & 37.97 & 37.86 \\
\hline Lipid\% & 13.04 & 14.72 & 13.62 & 13.83 & 13.04 \\
\hline Fibre (g/100 g) & 1.32 & 1.50 & 1.59 & 1.68 & 1.77 \\
\hline
\end{tabular}

Notes: Vitamin and mineral premix per kg: Vitamin A (UI) 1335000, vitamin D3 (UI) 500000, vitamin E (UI) 16670, vitamin K3 (mg) 3335, vitamin B1 (mg) 6670, vitamin B2 (mg) 5835, vitamin B6 (mg) 6670, vitamin B12 (mg) 3.35, folic acid (mg) 835, dcalpan (mg) 20000, vitamin C mono-phosphate (mg) 33335, inositol (mg) 45000, iron (mg) 8335, zinc (mg) 16670, manganese (mg) 3000, copper (mg) 8335, cobalt (mg) 670, iodine (mg) 167.5 and selenium (mg) 67.5.

Similar diets of which added chrome oxide (1\%) (by replacing apart of cassava meal and wheat flour (for 75FMR) were formulated to determine digestibility 
Table 3. ANFs presence (\%) in lupin and its fermentation product

\begin{tabular}{llll}
\hline Ani-nutritional factors & Lupin & Fermented lupin & Pooled S.E.M \\
\hline Phytic acid (phytate salt) & $0.54^{\mathrm{a}}$ & $0.07^{\mathrm{b}}$ & 0.006 \\
Tamins & $0.17^{\mathrm{a}}$ & $0.14^{\mathrm{b}}$ & 0.003 \\
\hline
\end{tabular}

Note: Within rows, values followed by the same letters are not significantly different $(p<0.05$, pair $T$ test) 
Table 4. Growth performance, SGR and feed intake of fish fed fishmeal diet and fishmeal partly replaced by fermented lupin diets. SGR and FCR denotes for specific growth rate and feed conversion rate.

\begin{tabular}{|c|c|c|c|c|c|c|}
\hline Parameters & OFMR & 30FMR & 45FMR & 60FMR & 75FMR & Pooled S.E.M \\
\hline Initial weight (g) & $6.8^{\mathrm{a}}$ & $7.2^{\mathrm{a}}$ & $6.9^{\mathrm{a}}$ & $6.9^{\mathrm{a}}$ & $6.9^{\mathrm{a}}$ & 0.68 \\
\hline Initial length (cm) & $7.7^{\mathrm{a}}$ & $7.9^{\mathrm{a}}$ & $7.8^{\mathrm{a}}$ & $7.8^{\mathrm{a}}$ & $7.8^{\mathrm{a}}$ & 0.45 \\
\hline Final weight (g) & $30.3^{\mathrm{a}}$ & $33.3^{\mathrm{a}}$ & $34.6^{\mathrm{b}}$ & $34.6^{b}$ & $31.4^{\mathrm{ab}}$ & 0.38 \\
\hline Final length $(\mathrm{cm})$ & $13.0^{\mathrm{a}}$ & $13.8^{a b}$ & $13.8^{\mathrm{ab}}$ & $14.0^{\mathrm{b}}$ & $12.9^{c}$ & 0.58 \\
\hline SGR (\%) & 2.45 & 2.50 & 2.61 & 2.63 & 2.47 & 0.33 \\
\hline Feed intake (g) & $991.7^{a}$ & $1080.7^{b}$ & $1085.0^{b}$ & $1085.4^{b}$ & $903.7^{c}$ & 0.36 \\
\hline FCR & $1.11^{\mathrm{a}}$ & $1.06^{\mathrm{a}}$ & $1.05^{\mathrm{a}}$ & $1.08^{a}$ & $1.21^{\mathrm{b}}$ & 0.28 \\
\hline Survival (\%) & $96.0^{\mathrm{a}}$ & $98.0^{\mathrm{a}}$ & $96.0^{a}$ & $93.0^{\mathrm{b}}$ & $93.0^{\mathrm{b}}$ & 0.07 \\
\hline \multicolumn{7}{|c|}{ Size distribution statistics } \\
\hline Skewness for weight & -0.179 & -0.096 & -0.091 & -0.124 & 0.062 & \\
\hline Skewness for length & -0.126 & 0.169 & -0.360 & -0.262 & -0.408 & \\
\hline
\end{tabular}

Note: Within rows, values followed by the same letter are not significantly different $(\mathrm{p}<0.05, \mathrm{LSD}$ test) 
Table 5. Digestibility (\%) of diets containing different FL inclusion levels and FL ingredient in test diets

\begin{tabular}{|c|c|c|c|c|c|c|}
\hline \multirow[b]{2}{*}{ AD (\%) } & \multicolumn{5}{|c|}{ Diets } & \multirow{2}{*}{$\begin{array}{r}\text { Pooled } \\
\text { S.E.M }\end{array}$} \\
\hline & OFMR & 30FMR & 45FMR & 60FMR & 75FMR & \\
\hline \multicolumn{7}{|l|}{ Diets } \\
\hline Protein & $91.37^{a}$ & $89.79^{a}$ & $94.79^{a}$ & $94.78^{a}$ & $96.59^{a}$ & 1.82 \\
\hline Hydrolyzed fat & $92.14^{a}$ & $89.20^{b}$ & $94.96^{\mathrm{ac}}$ & $96.22^{\mathrm{ac}}$ & $97.81^{c}$ & 1.54 \\
\hline Energy & $88.25^{a}$ & $87.57^{a}$ & $93.63^{a b}$ & $94.43^{a b}$ & $96.48^{b}$ & 1.09 \\
\hline Fiber & $40.53^{a}$ & $47.14^{\mathrm{a}}$ & $54.76^{\mathrm{a}}$ & $48.07^{\mathrm{a}}$ & $89.10^{b}$ & 4.90 \\
\hline Phosphorus & $49.09^{a}$ & $69.70^{\mathrm{b}}$ & $89.81^{c}$ & $92.23^{c}$ & $96.19^{c}$ & 4.75 \\
\hline \multicolumn{7}{|l|}{ Ingredient-FL } \\
\hline Protein & & 86.14 & 68.10 & 98.32 & 97.72 & 6.47 \\
\hline Hydrolyzed Fat & & $59.24^{a}$ & $67.28^{a}$ & $98.94^{b}$ & $99.18^{b}$ & 5.62 \\
\hline Energy & & $86.00^{a}$ & $70.43^{b}$ & $98.54^{c}$ & $99.21^{c}$ & 3.64 \\
\hline Fiber & & $62.42^{a}$ & $58.71^{a}$ & $53.10^{a}$ & $108.64^{b}$ & 6.78 \\
\hline Phosphorus & & 117.85 & 123.73 & 120.96 & 111.82 & 1.83 \\
\hline
\end{tabular}

Note: within rows, values followed by the same letter are not significantly different $(p<0.05$, Tukey's HSD test) 
Table 6. Body composition (\%) and essential amino acids (histidine (His), threonine (Thr), arginine (Arg), valine (Val), methionine (Met), lysine (Lys), Isoleucine (Iso), leucine (Leu), phenylalanine (Phe) and tryptophan (Try)) of initial fish and fish fed test diets after 61 days.

\begin{tabular}{|c|c|c|c|c|c|c|c|c|c|c|c|c|c|c|}
\hline \multirow[t]{2}{*}{ Diets } & \multicolumn{4}{|c|}{ Body proximate } & \multicolumn{10}{|c|}{ Essential amino acids } \\
\hline & Moisture & Protein & Fat & Energy & His & Thr & Arg & Val & Met & Lys & Iso & Leu & Phe & Try \\
\hline Initial & 78.27 & $17.21^{\mathrm{a}}$ & $1.00^{\mathrm{a}}$ & $0.79^{a}$ & 2.52 & $4.78^{a}$ & $7.13^{\mathrm{a}}$ & $6.88^{\text {abcde }}$ & $4.61^{a}$ & $11.31^{\mathrm{abf}}$ & $6.22^{\text {ade }}$ & $9.47^{\mathrm{ae}}$ & $10.65^{a}$ & $1.31^{a}$ \\
\hline OFMR & 79.00 & $16.38^{a}$ & $0.50^{b}$ & $0.70^{a}$ & 2.99 & $6.39^{b}$ & $7.39^{\mathrm{ab}}$ & $4.61^{\text {abcef }}$ & $8.24^{b}$ & $14.34^{\text {be }}$ & $7.02^{b}$ & $10.56^{\text {abe }}$ & $13.42^{b}$ & $1.26^{\mathrm{a}}$ \\
\hline 30FMR & 78.07 & $15.40^{\mathrm{b}}$ & $0.43^{b}$ & $0.67^{b}$ & 2.55 & $5.76^{b}$ & $7.93^{\mathrm{ab}}$ & $6.29^{\mathrm{abcef}}$ & $4.47^{a}$ & $11.26^{\text {acf }}$ & $5.95^{\text {cde }}$ & $9.17^{\mathrm{ce}}$ & $12.36^{c}$ & $1.30^{\mathrm{a}}$ \\
\hline 45MFR & 75.53 & $14.43^{b}$ & $0.40^{b}$ & $0.62^{b}$ & 2.65 & $5.69^{b}$ & $6.40^{c}$ & $6.01^{\text {adef }}$ & $4.68^{a}$ & $20.73^{d}$ & $5.54^{\text {de }}$ & $7.57^{d}$ & $7.25^{d}$ & $1.09^{b}$ \\
\hline 60FMR & 78.60 & $15.10^{b}$ & $0.46^{b}$ & $0.65^{b}$ & 2.93 & $6.13^{b}$ & $7.11^{\mathrm{abcd}}$ & $6.90^{\text {abcde }}$ & $5.11^{a}$ & $13.72^{\text {be }}$ & $6.24^{\text {abcde }}$ & $7.61^{c}$ & $9.10^{\mathrm{e}}$ & $1.30^{\mathrm{a}}$ \\
\hline 75FMR & 79.23 & $15.73^{b}$ & $0.52^{b}$ & $0.67^{b}$ & 2.85 & $2.57^{c}$ & $8.26^{\mathrm{ce}}$ & $6.49^{\mathrm{bf}}$ & $4.58^{a}$ & $11.18^{\text {acf }}$ & $5.87^{\mathrm{e}}$ & $9.38^{\mathrm{e}}$ & $12.22^{c}$ & $1.25^{\mathrm{a}}$ \\
\hline Pooled S.E.M & 0.53 & 0.23 & 0.05 & 0.01 & 0.05 & 0.32 & 4.48 & 0.19 & 0.33 & 0.83 & 0.13 & 0.27 & 0.52 & 0.02 \\
\hline $\mathrm{p}<\mathrm{F}$ & 0.47 & 0.00 & 0.00 & 0.00 & 0.09 & 0.00 & 0.00 & 0.00 & 0.00 & 0.00 & 0.02 & 0.00 & 0.00 & 0.01 \\
\hline
\end{tabular}

Note: Within columns, values followed by the same letter are not significantly different $(p<0.05$, Tukey's HSD test) 
Table 7. Nutrient retention (\%) in different FL inclusion levels in diets

\begin{tabular}{lccc}
\hline Diets & Protein & Lipid & Energy \\
\hline OFMR & $37.07^{\mathrm{a}}$ & 0.478 & 2.98 \\
30FMR & $31.71^{\mathrm{b}}$ & 0.54 & 2.64 \\
45MFR & $29.27^{\mathrm{b}}$ & 0.51 & 2.62 \\
6OFMR & $30.47^{\mathrm{b}}$ & 0.63 & 2.77 \\
75FMR & $31.70^{\mathrm{b}}$ & 0.71 & 3.03 \\
\hline Pooled S.E.M & 0.75 & 0.28 & 0.68 \\
p<F & 0.00 & 0.33 & 0.42 \\
\hline
\end{tabular}

Note: within columns, values followed by the same letter are not significantly different $(p<0.05$, Tukey's HSD test) 

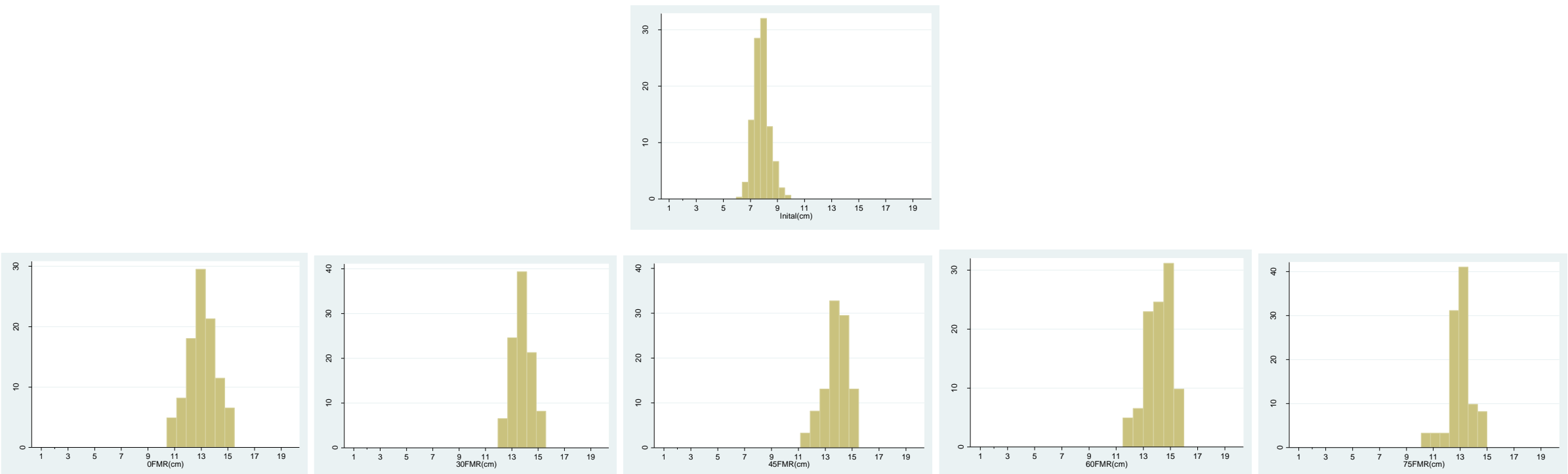

Figure 1. Histogram of length distribution of the fish of initial group and groups fed different FL inclusion levels in diets after 61 days.
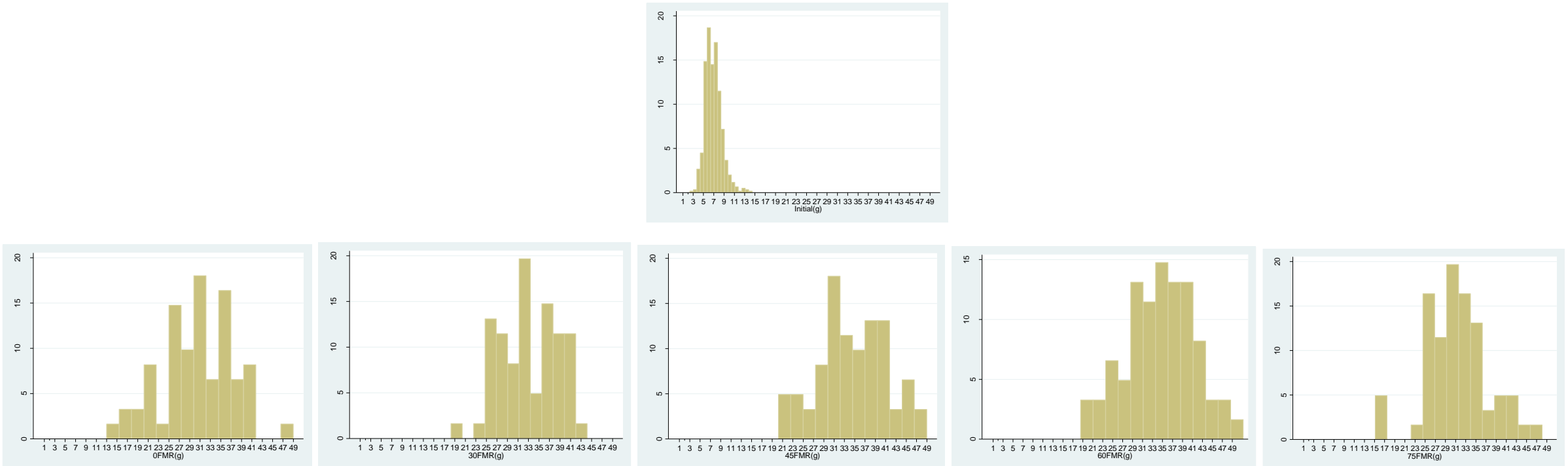

Figure 2. Weight distribution of the fish of initial group and groups fed different FL inclusion levels in diets after 61 days. 
Table 8. Regression relationships betweentwo phytates level and FCR, ADC of protein, ADC of fat, ADC of energy, $A D C$ of fiber and ADC of phophorus. In equations, $y$ denotes for phytates and $x$ denotes for the parameters in the same row.

\begin{tabular}{llll}
\hline Parameters & Equations & $R^{2}$ & $p$ \\
\hline FCR & $y=0.112 x^{2}-0.189 x+1.1028$ & 0.96 & 0.03 \\
Protein & $y=0.0002 x^{2}-0.0334 x+2.1754$ & 0.77 & 0.2 \\
Hydrolyzed fat & $y=2.6042 x^{2}-2.1167 x+91.594$ & 0.76 & 0.2 \\
Energy & $y=1.5655 x^{2}+1.1773 x+87.685$ & 0.85 & 0.1 \\
Fiber & $y=15.483 x^{2}-13.733 x+42.574$ & 0.77 & 0.2 \\
Phosphorus & $y=-6.7333 x^{2}+37.566 x+48.054$ & 0.96 & 0.04 \\
\hline
\end{tabular}




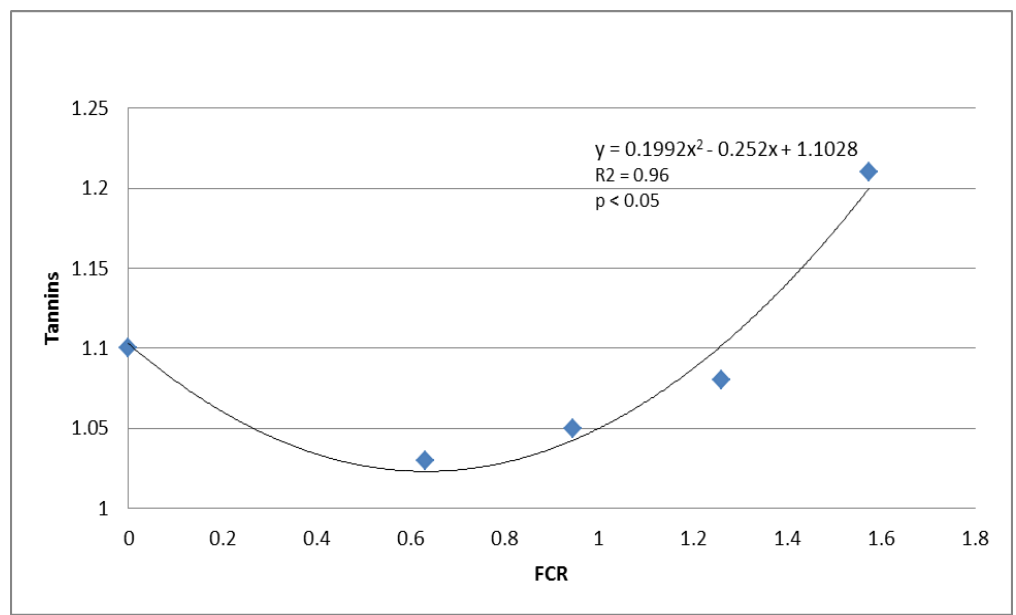

Figure 3. Regression of Tannins concentration in diets and FCR. The concentration was calculated based on the Tannins concentration in the lupin and inclusion levels of each test diets 